\title{
ZONING OF KIMBERLITE PROVINCES AND EVOLUTION OF KIMBERLITE MAGMATISM
}

Safronov A.F.

Yakutian Institute of Geosciences, Yakutsk, Russia, 677892.

Zoning is a fundamental feature of kimberlite provinces (Kaminsky, 1972; Milashev, 1974). In the best studied South-African and Yakutian provinces, it manifests in a trend-wise variation of a range of parameters, permitting us to distinguish two types of subprovinces:

- intracontinental ones;

- those of marginal parts of platforms.

The subprovinces have the following distinctive features:

1. Intracontinental subprovinces:

- contain only classic kimberlites which compose pipes and dykes, including primary diamondiferous deposits;

- the upper mantle material of the kimberlites is a relatively "cool", "depleted" and differentiated substance, including diamondiferous rocks and minerals of diamond paragenesis;

- only "classic" kimberlites are known in them.

2. Subprovinces of marginal parts of platforms (passive continental margins):

- contain sterile or poorly diamondiferous kimberlites, as well as diamondiferous placers of different ages, even older than kimberlites;

- the upper mantle material of the kimberlites is a relatively "warmed-up" and less differentiated matter;

- widely distributed, along with the so-called "classic" kimberlites, are kimberlitoides or "molnoites";

- in addition to kimberlites similar in age to the intracontinental ones, there are younger kimberlites, poorer in both diamonds and minerals of diamond association (Pokhilenko et al., 1990).

Comparison of the subprovinces of the two types suggests that the zoned structure of the kimberlite provinces is a reflection of the following phases of evolution of kimberlite magmatism in space and time:

(i) Initiation of kimberlite magmatism at the expense of the "cool", "depleted" and differentiated upper mantle results in the emplacement of "classic" kimberlites.

(ii) Subsequent igneous activity is related to recurrent

tectonothermal events that cause warming-up and secondary enrichment of upper mantle material and resorption of diamonds. Kimberlites turn poorly diamondiferous and non-diamondiferous; molnoites are emplaced in close spatial and temporal association with the kimberlites.

(iii) This phase is probably related to destruction of the continental lithosphere, formation of the oceanic lithosphere, and opening of sea basins. As a result, kimberlite provinces acquire the above mentioned zoned structure, with spatially associated diamondiferous placers forming in marginal parts of platforms from erosion of older, diamondiferous kimberlites and "molnoites".

Such a scenario of kimberlite magmatism lends explanation for a wide distribution of diamondiferous placers in passive continental margins or marginal parts of platforms, in areas of non-diamondiferous kimberlites and rocks convergent with kimberlites (South West Africa, South Brazil, East Australia, Borneo, North Yakutia). 
References.

Kaminsky F.V., 1972. Doklady Acad. Nauk SSSR, v.204, n.5. Mllashev V.A., 1974. Kimberlite provinces, Nedra, Leningrad.

Pokhilenko N.P., Sobolev N.V., Safronov A.F., Lavrentiev Yu.G., Amshinsky A.N., Rodionov A.S., Blinchik T.M., 1988, Composition and processes of deep-seated zones of continental lithosphere. Abstracts, Novosibirsk. 